\title{
Practices and Factors Influencing the Use of Antibiotics in Selected Poultry Farms in Ghana
}

Boamah, VE; Odoi, H; Dalsgaard, Anders

Published in:

Journal of Antimicrobial Agents

DOI:

$10.4172 / 2472-1212.1000120$

Publication date:

2016

Document license:

CC BY

Citation for published version (APA):

Boamah, VE., Odoi, H., \& Dalsgaard, A. (2016). Practices and Factors Influencing the Use of Antibiotics in Selected Poultry Farms in Ghana. Journal of Antimicrobial Agents, 2(2), [1000120]. https://doi.org/10.4172/24721212.1000120 


\title{
Practices and Factors Influencing the Use of Antibiotics in Selected Poultry Farms in Ghana
}

\section{Boamah VE ${ }^{1}$, Agyare $\mathrm{C}^{1 *}$, Odoi $\mathrm{H}^{1}$ and Dalsgaard $\mathrm{A}^{2}$}

${ }^{1}$ Department of Pharmaceutics (Microbiology Section), Faculty of Pharmacy and Pharmaceutical Sciences, Kwame Nkrumah University of Science and Technology, Kumasi, Ghana

${ }^{2}$ Section of Food Safety and Zoonoses, Department of Veterinary Disease Biology, Faculty of Health and Medical Sciences, University of Copenhagen, Denmark

\begin{abstract}
Many of the antibiotics employed in animal production also serve as essential medicines for use in humans. However, only a handful of studies address antibiotic use in animal husbandry in Ghana. The aim of this study was to investigate the use of essential antibiotics in poultry production in Ghana and to assess factors influencing farmers' choice of antibiotics for use on their farms. A cross-sectional survey using questionnaires and semistructured interviews was conducted among 400 poultry farms in the Ashanti, Brong-Ahafo and Greater Accra regions of Ghana. Data was analysed using IBM SPSS and Microsoft Excel. Multivariate analyses were used to evaluate correlations between farm variables and the dependency of antibiotic use on internal and external farm characteristics. Farmers reported the use of 35 different antimicrobial agents for management of conditions such as Newcastle, fowl pox, coccidiosis, and coryza. From these agents, 20 essential antibiotics belonging to 10 antibiotic classes were extracted. Frequently employed antibiotics were tetracyclines $(24.17 \%)$, aminoglycosides $(17.87 \%)$, penicillins $(16.51 \%)$ and fluoroquinolones $(10.55 \%)$. Only $63 \%$ of the farms completed recommended antibiotic course durations, $58 \%$ reported following recommended withdrawal periods and $88 \%$ sought veterinary advice before administration of antibiotics. Farmers had easy access to antibiotics and antibiotic-related information from veterinary offices, vet-chemical shops and mobile salesmen. Correlation analysis showed farm activities such as frequency of change of bedding material, disinfectant use and seeking expert advice correlated significantly with size and age. The use of antibiotic-containing agents was observed to be dependent on internal factors such as size, presence of other livestock on the farm and infections. External factors such as easy access to antibiotics also influenced farmers' use of antibiotics. These findings call for stricter regulations on access to and use of antibiotics on poultry farms in Ghana.
\end{abstract}

Keywords: Antibiotics; Poultry; Essential medicines; Antibiotic combinations; Survey; Antibiotic choice; Ghana

\section{Introduction}

The agricultural sector in Ghana employs close to $55 \%$ of the total workforce of the country's population and this accounts for about $40 \%$ of the country's gross domestic product (GDP), with the livestock industry (cattle, goats, grasscutters, sheep, pigs and poultry) forming about $6 \%$ of the sector $[1,2]$. The livestock industry in Ghana, like most developing countries, is not as well-established with structured management systems, mechanised technology and high level of production as those of developed countries [3].

The poultry industry in Ghana consists of both local and foreign birds with almost each household keeping a few birds for protein supplementation (meat and egg) and for sale [1,4-6]. Commercial poultry farms have large numbers of mostly foreign breeds of gallus under the intensive system. The disadvantage associated with this system is the ease with which diseases spread among birds when there is an outbreak of an infectious disease, which could lead to loss of both birds and capital. In order to prevent such loses and also to enhance the growth of birds, farmers resort to the use of various antibiotics [7].

Many of these antibiotics employed in animal production also serve as essential medicines for use in humans in many countries $[7,8]$. With the global increase in antibiotic resistance, there is the need for all countries to preserve the effectiveness of essential antibiotics, especially those that are of critical importance [9-11]. It has been reported that the misuse of antibiotics in food-animal production is one of the most important factors contributing to the global surge and spread in antibiotic resistance [12].
Several studies have reported high level of antibiotic resistant bacteria isolated from patients visiting healthcare facilities in Ghana [13-17] and even among the healthy populace [18]. These reports show an increase in antibiotic resistance in both commensals and pathogenic bacteria and this raises a concern to public health system.

Studies on antibiotic use in animal husbandry including the poultry sector and their impact on antibiotic resistance in Ghana are very few [4]. There have however been previous reports of the misuse of essential antibiotics such as tetracyclines, tylosin, chloramphenicol and neomycin $[7,19]$ even though the use of these agents as growth promoters in foodanimals had been banned in most parts of Europe [20]. Veterinarians are the authorized professionals responsible for diagnosis, prescriptions and administration of antibiotics to farm animals in many developed countries [21]. In contrast, antimicrobial use by livestock producers in most developing countries are not as well monitored or controlled [21]

Essential considerations such as the economy, efficiency and

*Corresponding author: Dr. Christian Agyare, Department of Pharmaceutics (Microbiology Section), Faculty of Pharmacy and Pharmaceutical Sciences, Kwame Nkrumah University of Science and Technology, Kumasi, Ghana, Tel: +233246369803; E-mail: cagyare.pharm@knust.edu.gh

Received April 27, 2016; Accepted May 31, 2016; Published June 15, 2016

Citation: Boamah VE, Agyare C, Odoi H, Dalsgaard A (2016) Practices and Factors Influencing the Use of Antibiotics in Selected Poultry Farms in Ghana. J Antimicro 2: 120. doi:10.4172/2472-1212.1000120

Copyright: (c) 2016 Boamah VE, et al. This is an open-access article distributed under the terms of the Creative Commons Attribution License, which permits unrestricted use, distribution, and reproduction in any medium, provided the original author and source are credited. 
regulations [22] together with factors such as farmer characteristics and the biophysical properties of the farm [23] combine to influence decisions of farm management. Nonetheless, most of the reports on antibiotic use in food-animal production have been limited to the types of antibiotics employed, resistance of organisms isolated from these farms [24-28] and quantities of antibiotics used [25,26].

In Ghana, it has been reported that over $50 \%$ of poultry farmers rely on personal experience in the administration of antimicrobials to their animals [19]. Aside farmers' personal experience other factors likely to influence their choice of antibiotics have not been studied. These factors, if known, could be a guide on how to address and minimize the misuse of essential antibiotics in food animal production. This study, therefore, determines factors and practices that influence farmers' choice and use of antibiotics on selected poultry farms in three regions of Ghana, namely, the Ashanti, Brong Ahafo and Greater Accra regions.

\section{Study areas}

The study areas were the Ashanti, Brong Ahafo and Greater Accra regions of Ghana. These regions cover a total of $67,190 \mathrm{~km}^{2}$ representing $30 \%$ of Ghana's total land surface area. The population of the three regions is approximately 11.1 million, accounting for about $45 \%$ of the total population of Ghana [29]. The three regions contribute between $60 \%$ to $70 \%$ of the total poultry production in Ghana [1,30] (Figure 1).

\section{Materials and Methods}

\section{Survey}

A pilot study was carried out by administering questionnaires to 25 poultry farms in and around Kumasi, the capital town of the Ashanti region, Ghana, after which the validated questionnaires were administered to 400 poultry farms in the selected regions (Selection was done using snowball sampling and information obtained from the Veterinary division of Ministry of Food and Agriculture, Ghana) between June 2012 and July 2013. Structured face-to-face interviews with farm owners, managers and workers were carried out on the premises of selected farms. Additional information from farm record books and empty containers of medications were also obtained. Covert observation of farm activities (use of disinfectants and collection and sale of poultry products) was also employed.

\section{Categorization of farms}

Farms were divided into 3 categories namely; small (farms with less than 5,000 birds), medium (farms with 5,000-10,000 birds) and large (farms with more than 10,000 birds) as described and recommended by $[1,6,8]$.

\section{Data and statistical analysis}

Descriptive analysis of the various farm demographics was carried out. Correlations between selected variables such as the various farm demographics, disease history and antimicrobial practices were done using Spearman's rho ranking. The Student's T-test was employed in determining the differences in the use of the different classes of antimicrobial agents on the farms. Bivariate analyses were used to evaluate the dependency of twenty-one essential antibiotic-containing antimicrobial agents (individually) as dependent variables and intrinsic and extrinsic farm characteristics as independent variables.

\section{Results}

\section{Demographic information on surveyed farms}

Majority of the farms surveyed fell into the medium category, had layer birds and were established within the past 10 years. Wood shavings or saw dust was the most common bedding material (litter) used, with $35 \%$ of the farms changing their litter quarterly. Over $80 \%$ of the farms relied on underground water such as boreholes and wells (Table 1).

\section{Diseases treated on the farms}

Farmers diagnosed diseases affecting the birds based on their own experiences or through the assistance of a veterinarian. Eighty-two percent of farmers treated viral infections such as gumboro, New Castle and fowlpox. Bacterial infections such as chronic respiratory disease (CRD) and coryza were treated by $53 \%$ of the farms whereas coccidiosis and other parasitic infections were treated by $41 \%$ of the farmers.

\section{Antimicrobial agents used in selected farms}

Over 30 different antimicrobial agents were employed on the selected poultry farms. These agents (coded AMA) included brands such as aliseryl, alizadeth, amprolium, antibact, atcaryl, avatec, britacox, clopivet, clotadona, coccifulavet, cozuril, decazen, doxycycline, enromax, erodex, febretox, flordox, godox-n, hiproseryl, hypralona, narcox, nemovit, neo-vit-oxytet, neocol, neomycin and norflox. Others were oxytetracycline, pen-strep, pen-provit, streptomycin, tavet, TCN, trisol-otc, tylo-dox and tylovital (Figure 2).

\section{Purpose of antimicrobial use in the selected farms}

In all the selected farms in the three regions, different antimicrobial agents were employed mainly for treatment of infections and prophylactic purposes (Table 2). Vaccines for gumboro, New castle and fowl pox were also administered to prevent infections among birds. Coccidiostats were employed in the management of coccidiosis. Agents used as growth promoters were mainly amino acid and vitamin preparations.

\section{Essential antibiotics used by farmers}

In order to determine the various types of essential antibiotics used on poultry farms, the different brands of medications used on the farms were expanded to show their active ingredients (Table 3). Different brands with identical active ingredients were put in the same (Ama) group.

The various antibiotics used on the selected farms were categorised into the antibiotic classes described by the WHO and the Ghana National Drug Programme [9,31]. Antibiotic classes such as tetracyclines (24.18\%), aminoglycosides (18.88\%) fluoroquinolones (13.79\%) and penicillins $(12.86 \%)$ were the most frequent classes of antibiotics used in poultry farms in the selected areas for treatment of infections (Figure 3 ). The selected farms used significantly more tetracycline-containing agents than fluoroquinolone and aminoglycoside-containing $(\mathrm{p}<0.05)$ ones and more aminoglycoside-containing agents than fluoroquinolone and penicillin-containing $(\mathrm{p}<0.05)$ ones for treatment of poultry infections.

For prophylaxis, penicillins (26.218\%), tetracyclines $(24.13 \%)$ and aminoglycosides $(20.51 \%)$ were the most frequently used classes of antibiotics (Figure 4). There was no significant difference in the use of aminoglycosides, tetracyclines and penicillins as prophylactic agents in the selected farms $(\mathrm{p}>0.05)$. 
Citation: Boamah VE, Agyare C, Odoi H, Dalsgaard A (2016) Practices and Factors Influencing the Use of Antibiotics in Selected Poultry Farms in Ghana. J Antimicro 2: 120. doi:10.4172/2472-1212.1000120

Page 3 of 8

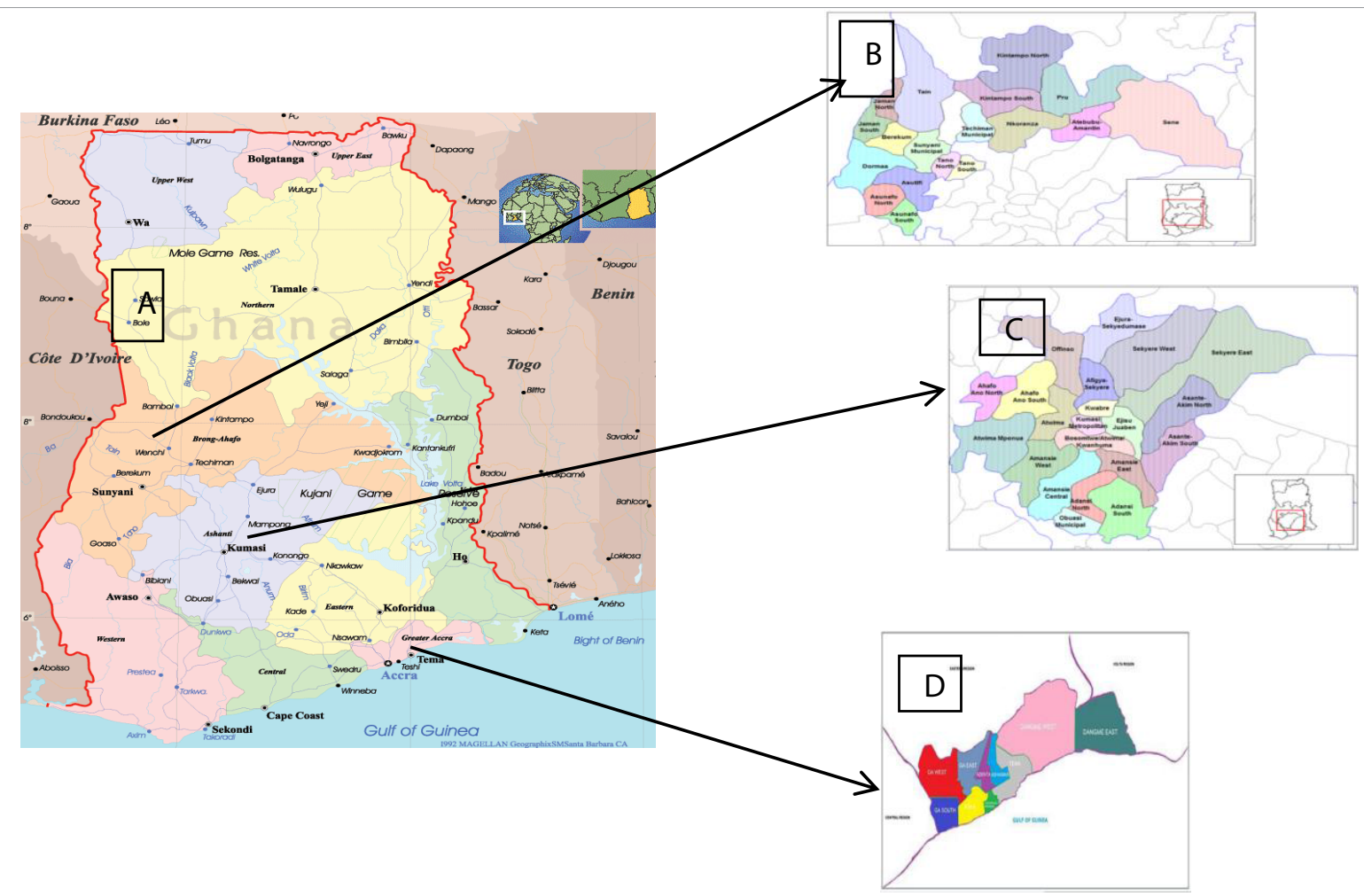

Figure 1: A map of Ghana showing the three selected regions where the study was carried out. A: administrative map of Ghana; B: Brong Ahafo region; C: Ashanti region; D: Greater Accra region. (Source www.cia.gov/library/publications/resources/cia-maps-pub/ghana/image.jpg).

\begin{tabular}{|c|c|c|c|c|c|c|c|c|}
\hline & & \multirow[b]{3}{*}{$\mathrm{N}_{\mathrm{T}}$} & \multicolumn{6}{|c|}{ Region } \\
\hline & & & \multicolumn{2}{|c|}{ Antibiotics } & \multicolumn{2}{|c|}{ Farm size } & \multicolumn{2}{|c|}{ Greater Accra } \\
\hline & & & $\mathrm{N}$ & Percentage (\%) & $\mathrm{N}$ & Percentage (\%) & $\mathrm{N}$ & Percentage (\%) \\
\hline Distribution of farms & & 400 & 244 & 61 & 114 & 28.5 & 42 & 10.5 \\
\hline \multirow{3}{*}{ Size } & Small & 82 & 54 & 22.1 & 14 & 12.3 & 14 & 33.3 \\
\hline & Medium & 254 & 143 & 58.6 & 84 & 73.7 & 27 & 64.3 \\
\hline & Large & 64 & 47 & 19.3 & 16 & 14.0 & 1 & 2.4 \\
\hline \multirow{3}{*}{ Types of birds } & Layers & 383 & 231 & 94.7 & 110 & 96.5 & 42 & 100 \\
\hline & Broilers & 72 & 35 & 14.3 & 15 & 13.2 & 22 & 52.4 \\
\hline & Breeders & 7 & 4 & 1.6 & 1 & 0.9 & 2 & 4.8 \\
\hline \multirow{4}{*}{$\begin{array}{l}\text { Age of farm } \\
\text { (years) }\end{array}$} & $0-5$ & 146 & 90 & 36.9 & 50 & 43.9 & 6 & 14.3 \\
\hline & $6-10$ & 102 & 60 & 24.6 & 26 & 22.8 & 16 & 38.1 \\
\hline & $11-20$ & 90 & 49 & 20.1 & 24 & 21.1 & 17 & 40.5 \\
\hline & Above 20 & 62 & 45 & 18.4 & 14 & 12.3 & 3 & 7.1 \\
\hline \multirow{2}{*}{ Type of litter } & Wood shaving & 385 & 243 & 99.6 & 112 & 98.3 & 30 & 71.4 \\
\hline & Battery cage & 15 & 1 & 0.4 & 2 & 1.7 & 12 & 28.6 \\
\hline Other livestock & & 100 & 57 & 23.4 & 37 & 32.5 & 6 & 14.3 \\
\hline \multirow{5}{*}{ Frequency of litter change } & Monthly & 92 & 48 & 19.7 & 43 & 37.7 & 1 & 2.4 \\
\hline & Quarterly & 141 & 91 & 37.3 & 43 & 37.7 & 7 & 16.7 \\
\hline & Every 4 months & 43 & 27 & 11.1 & 16 & 14.0 & 0 & 0.0 \\
\hline & Every 6 months & 61 & 40 & 16.4 & 8 & 7.0 & 13 & 31.0 \\
\hline & Yearly & 63 & 38 & 15.6 & 4 & 3.5 & 21 & 50.0 \\
\hline \multirow{3}{*}{ Source of water } & Well & 141 & 77 & 31.7 & 63 & 55.2 & 1 & 2.3 \\
\hline & Borehole & 183 & 121 & 49.8 & 32 & 28.1 & 30 & 69.8 \\
\hline & Pipe borne & 76 & 45 & 18.5 & 19 & 16.7 & 12 & 27.9 \\
\hline
\end{tabular}

Table 1: Demographics of selected poultry farms in the three regions. 
Citation: Boamah VE, Agyare C, Odoi H, Dalsgaard A (2016) Practices and Factors Influencing the Use of Antibiotics in Selected Poultry Farms in Ghana. J Antimicro 2: 120. doi:10.4172/2472-1212.1000120

Page 4 of 8

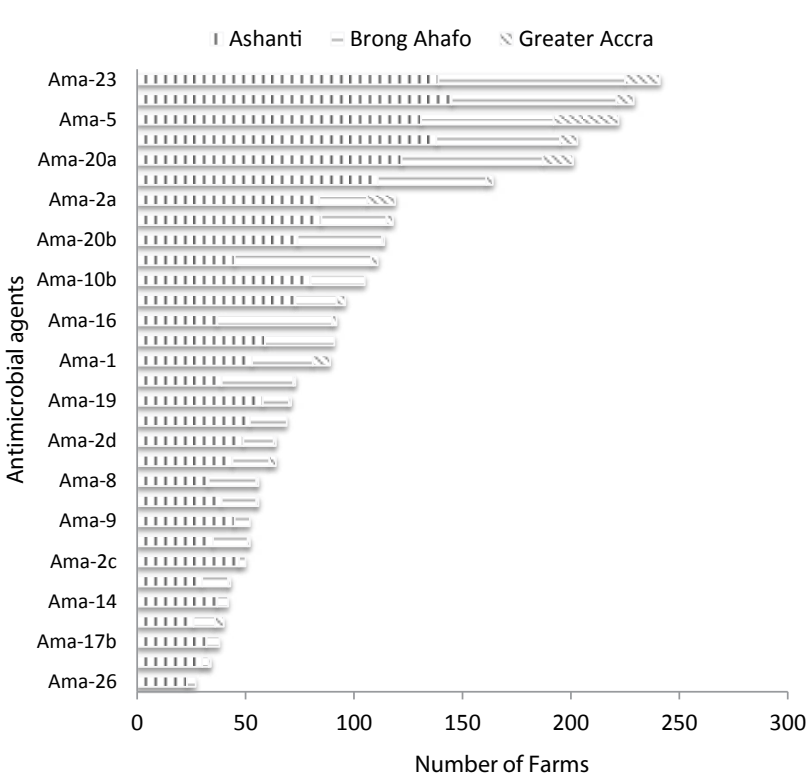

Figure 2: Antimicrobial agents used on the selected farms for treatment of infections in the three regions. Ama=Antimicrobial agent.

\begin{tabular}{|c|c|}
\hline Disease & $\begin{array}{c}\text { Antimicrobial agents } \\
\text { Viral infections }\end{array}$ \\
\hline $\begin{array}{c}\text { Gumboro } \\
\begin{array}{c}\text { Newcastle Disease } \\
\text { (NCD) }\end{array}\end{array}$ & $\begin{array}{c}\text { Ama-1, Ama-2, Ama-3, Ama-4, Ama-5, Ama-10, Ama-11, } \\
\text { and Ama-17. }\end{array}$ \\
\hline \multicolumn{2}{|c|}{$\begin{array}{c}\text { Ama-4, Ama-5, Ama-10, Ama-11, Ama-14, } \\
\text { Ama-17, and Ama-20. }\end{array}$} \\
$\begin{array}{c}\text { Bacterial infections } \\
\text { Disease (CRD) }\end{array}$ \\
\hline Coryza & $\begin{array}{c}\text { Ama-1, Ama-2, Ama-3, Ama-4, Ama-5, Ama-10, Ama-11, } \\
\text { Ama-12, Ama-13, Ama-14, AMa-17, Ama-18 and Ama-20. }\end{array}$ \\
\hline & Ama-4, Ama-5, Ama-8, Ama-10 and Ama-16. \\
\hline Parasitic infections \\
\hline Coccidiosis & $\begin{array}{c}\text { Ama-2, Ama-4, Ama-10, Ama-13, Ama-14, Ama-20, Ama-21 } \\
\text { and Ama-22. }\end{array}$ \\
\hline Worms & Ama: Antimicrobial agent \\
\hline
\end{tabular}

Table 2: Microbial infections and antimicrobial agents used in their management.

\section{Antibiotics used for both treatment and prophylaxis in the selected farms}

Essential antibiotics used by the selected farms in the three regions for treatment and prophylaxis were determined to ascertain the extent of use of such agents. A total of 10 antibiotic classes comprising 20 essential antibiotics (Table 4) were recorded. Among the three regions, tetracyclines $(24.17 \%)$, aminoglycosides $(17.87 \%)$, penicillins $(16.51 \%)$ and fluoroquinolones $(10.55 \%)$ were the most widely used antibiotics.

\section{Practices related to the use of antibiotics among poultry farms}

Of the 400 selected farms, $34 \%$ reported following recommended withdrawal periods, $68 \%$ kept treatment records and 50\% wrote down treatment plans. Eighty-eight percent sought veterinary or other expert advice before administration of antibiotics. Non-veterinarians including farm managers (48\%), farm owners (21\%), designated persons $(17 \%)$ or any of the farm workers (14\%) administered antibiotics on the selected farms. Veterinary officer administered antibiotics in $2 \%$ of the farms

\begin{tabular}{|c|c|}
\hline Agent & Active ingredient \\
\hline Ama-1 ${ }^{1}$ & $\begin{array}{l}\text { Erythromycin, oxytetracycline, streptomycin, } \\
\text { neomycin, colistin }\end{array}$ \\
\hline $\begin{array}{l}\text { Ama-2a } a^{1}, \text { Ama-2 } b^{1}, \text { Ama- } \\
2 c^{1}, \text { Ama-2d }\end{array}$ & $\begin{array}{c}\text { Erythromycin, oxytetracycline, streptomycin, } \\
\text { colistin }\end{array}$ \\
\hline Ama-3 ${ }^{1}$ & Tylosin, oxytetracycline, neomycin \\
\hline Ama-4, $4^{1,2}$ & Tetracycline, chloramphenicol, neomycin \\
\hline Ama-5,2 & $\begin{array}{l}\text { Procaine penicillin, benzathine penicillin, } \\
\text { streptomycin }\end{array}$ \\
\hline Ama-6 ${ }^{1}$ & Sulphadimidine, pyremethamine, tetracycline \\
\hline Ama- $7^{2}$ & Gentamicin, sulphamethoxazole, trimethoprim \\
\hline Ama-8 $8^{1,2}$ & Erythromycin, neomycin \\
\hline Ama-91 & Neomycin, colistin \\
\hline Ama-10a $a^{1,2}$, Ama-10 $b^{1}$ & Tylosin, doxycycline \\
\hline Ama-11a $a^{2}$ Ama-11 $b^{2}$ & Oxytetracycline, neomycin \\
\hline Ama-12 & Norfloxacin, doxycycline \\
\hline Ama-13 1 & Florfenicol, doxycycline \\
\hline Ama-14 1 & Doxycycline, neomycin \\
\hline Ama-15 1 & Chloramphenicol \\
\hline Ama-16 1 & Doxycycline \\
\hline $\begin{array}{l}\text { Ama-17a, } a^{2}, \text { Ama-17b } \\
\text { Ama-17c }\end{array}$ & Enrofloxacin \\
\hline Ama-18 & Neomycin \\
\hline Ama-191 & Norfloxacin \\
\hline Ama-20a $a^{1}$, Ama-20 $b^{1}$ & Oxytetracycline \\
\hline Ama-21 ${ }^{1}$ & Streptomycin \\
\hline Ama-22 ${ }^{1}$ & Sulphadiazine \\
\hline \multicolumn{2}{|c|}{$\begin{array}{l}\text { Ama: Antimicrobial agent used by farmers; }{ }^{1} \text { antimicrobial agent used for } \\
\text { treatment of infections, }{ }^{2} \text { antimicrobial agent used as prophylactic agent }\end{array}$} \\
\hline
\end{tabular}

Table 3: Antibiotic-containing agents used on selected poultry farms.

and $63 \%$ of the farms completed recommended antibiotic course durations.

\section{Access to antibiotics and information related to antibiotics}

Most of the farmers did not have difficulty accessing antibiotics of choice and information related to antibiotics of choice (Table 5).

\section{Relationship between farm characteristics}

The size of a farm was significantly $(\mathrm{p}=0.01$ ) related to the age of the farm. Both larger and older farms change their litter more frequently than smaller and younger farms $(p=0.01)$. Large farms significantly recorded incidents of Newcastle disease (NCD) $(\mathrm{p}=0.04)$, coccidiosis $(\mathrm{p}=0.04)$ and chronic respiratory disease $(\mathrm{CRD})(\mathrm{p}=0.01)$ than smaller farms. Older farms also recorded higher incidents of NCD $(p=0.01)$ compared to new farms whereas smaller farms had a significant probability of recording coryza $(\mathrm{p}=0.04)$ (Figure 5).

Poultry farms rearing other different livestock were less likely to seek veterinarian advice $(\mathrm{p}=0.04)$ and use disinfectants $(\mathrm{p}=0.02)$ than farms with only poultry. Farms with wood shavings as bedding material significantly recorded more coccidiosis $(p=0.02)$ and NCD $(p=0.01)$ than farms that used battery cage systems. Farms that used disinfectants also recorded lesser incidents of NCD on their farms $(p=0.03)$ than farms that did not (Figure 5).

Farm characteristics that influence the use of essential antibiotics

Farm characteristics were categorised into internal (those 


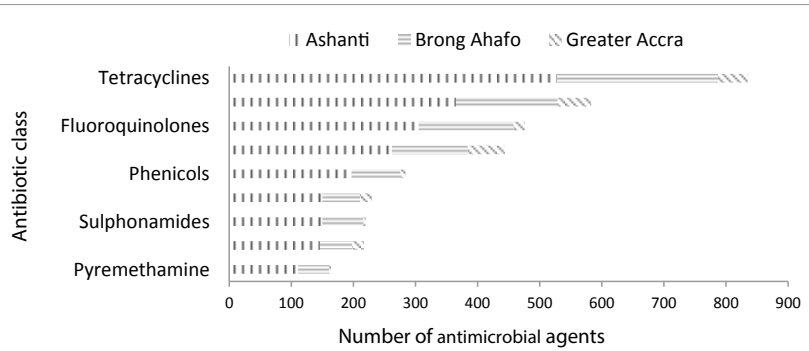

Figure 3: Groups of antibiotics used for treatment of infections in the selected farms.

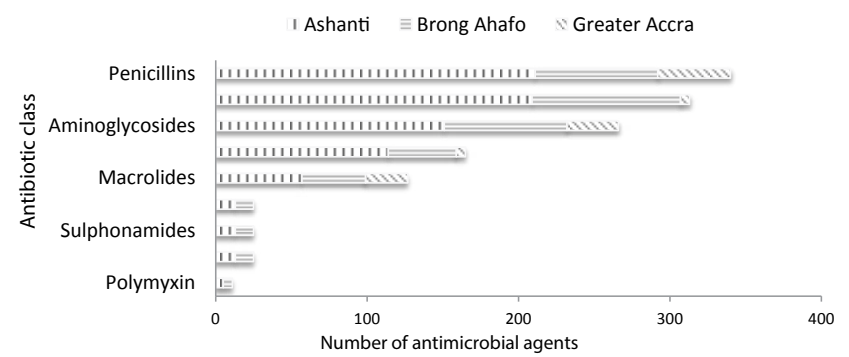

Figure 4: Groups of antibiotics used for prophylaxis in the selected farms.

characteristics directly under the jurisdiction of the farmer) and external (characteristics not under the control of the farmer). Internal farm characteristic such as farm size, age, keeping other livestock together with poultry, and occurrence of infections such as coccidiosis and CRD significantly increased the use of close to $30 \%$ of the antibioticcontaining agents. However, the bedding material used on the farm and infections such as gumboro, fowlpox and coryza influenced the used of less than $5 \%$ of the antibiotic-containing agents. The use of 38 to $43 \%$ of the antibiotic-containing agents significantly depended on factors outside the control of the farmer, such as seeking expert or veterinarian advice, buying from veterinary sources and ease of access to antibiotics (Table 6).

\section{Discussion}

Misuse of antibiotic is considered the most important factor selecting for emergence of antibiotic resistance [32]. The misuse of antibiotics in animal husbandry has also been associated with the spread of antibiotic resistance [12]. Despite the increasing resistance of pathogenic bacterial strains in Ghana [33], there are only a few reports on antibiotics used in animal production, how they are used and possible factors influencing their selection, hence the need for this study.

A total of 400 poultry farms were selected from three regions for the study. Most of the selected farms were medium and small sized farms (Table 1). The high prevalence of small and medium farms could be due to consumption and demand pattern in the regions which necessitates keeping small and medium size poultry farms compared to larger ones. Most of the farms (96\%) also kept layer birds which could be due to the fact that farmers gained more from layer birds, which produce both eggs and meat, than from broiler birds which provide only meat [34].

In about $96 \%$ of the selected farms, sawdust was the bedding material used. This could be because sawdust is economically cheaper than other beddings or the battery cage method. However, it has been reported that certain poultry disease conditions such as coccidiosis and chronic respiratory disease (CRD) could be transmitted through contact with poultry beddings such as sawdust [35]. This situation may also be compounded by the low rate at which bedding are changed since only about $23 \%$ of the selected farms changed their bedding material monthly or more frequently (Table 1 ).

Diseases treated on the selected poultry farms included poultry infections of viral, bacterial, protozoal and other parasitic sources which are known to be common infections among poultry $[19,35,36]$. Such infections could be a major cause of financial loss $[37,38]$ and as such, farmers try as much as possible to prevent and also treat them. Some non-pharmacological means of preventing diseases among poultry are timely vaccination, good nutrition, reducing overcrowding and increasing farm hygiene practices [39].

Antimicrobials used in animal production are employed for both therapeutic and non-therapeutic purposes [7,40,41]. Farmers in the selected regions employed several antimicrobial agents for treatment of infections and for prophylaxis (Table 2). This observation is similar to that previously reported $[7,19]$ in which antimicrobial agents employed on poultry farms in some Ghanaian communities were mainly for treatment and prevention of infections and as growth promoters. This study has also revealed that more than half of antibiotic-containing agents employed on poultry farms contained between two and five different antibiotics (Table 3). The inappropriate use of these agents could accelerate the development of microbial resistance to the different groups of antibiotics $[42,43]$. The use of same antibiotics for treatment and prevention of poultry infections and as growth promoters has been reported in other African countries $[38,44,45]$.

In approximately $98 \%$ of the selected farms, non-veterinary persons administered antibiotics to poultry birds. The administration of antibiotics by such individuals could lead to under-dosing or over-dosing of birds [46]. In several European countries such as The Netherlands, Denmark, Norway and Sweden, the administration of antibiotics to farm animals are strictly under the supervision of a veterinarian [42]. Ghana does not have enough veterinarians to enforce such regulations [47]. In the absence of these experts, persons such as the farm owners and managers should be adequately trained to perform such responsibilities.

The administration of the correct dose of an antibiotic is as important as the completion of the antibiotic course [46]. Incompletion of antibiotic treatment courses exposes the microorganisms to subinhibitory concentrations of the antibiotic $[43,48]$ which leads to the development of resistance. The fact that only $63 \%$ of the selected farms completed the required antibiotic courses could be due to the absence of veterinarians on farms to supervise antibiotic administration or lack of knowledge on the farmers' part on the outcome of such practices [49].

In order to reduce traces of antibiotic residues to humans, livestock farmers are required to observe withdrawal period after administration of antibiotics during which products from their farms are not to be sold $[40,50]$. This study showed that over $60 \%$ of the farmers failed to adhere to the recommended withdrawal period. Failure of farmers in observing withdrawal period has been attributed to the financial loss that may arise with observance of the withdrawal periods $[7,19]$ since products such as eggs obtained within the period have to be discarded.

Non-observance of withdrawal period has however, been linked to detection of unacceptably high levels of aminoglycosides, betalactams, chloramphenicol, macrolides, sulphonamides, tetracyclines 
Citation: Boamah VE, Agyare C, Odoi H, Dalsgaard A (2016) Practices and Factors Influencing the Use of Antibiotics in Selected Poultry Farms in Ghana. J Antimicro 2: 120. doi:10.4172/2472-1212.1000120

Page 6 of 8

\begin{tabular}{|c|c|c|c|}
\hline Antibiotic class & Essential antibiotic & Frequency & Percentage $(\%)$ \\
\hline Tetracyclines & Tetracycline, oxytetracycline and doxycycline & 1148 & 24.17 \\
\hline Aminoglycosides & Neomycin, streptomycin and gentamicin & 849 & 17.87 \\
\hline Penicillins & Benzyl penicillin and Procaine penicillin & 784 & 16.51 \\
\hline Fluoroquinolones & Norfloxacin, enrofloxacin & 501 & 10.55 \\
\hline Phenicols & Chloramphenicol and Florfenicol & 449 & 9.45 \\
\hline Macrolide & Erythromycin and tylosin & 357 & 7.52 \\
\hline Sulphonamides & Sulphamethoxazole, Sulfadimidine and Sulphadiazine & 245 & 5.16 \\
\hline Polymyxin & Colistin & 228 & 4.80 \\
\hline Pyremethamine & Pyremethamine & 164 & 3.45 \\
\hline
\end{tabular}

Table 4: Antibiotics used for both treatment and prophylaxis in the selected farms.

\begin{tabular}{|c|c|c|c|c|c|c|c|}
\hline & & \multicolumn{6}{|c|}{ Region } \\
\hline & & \multicolumn{2}{|c|}{ Ashanti } & \multicolumn{2}{|c|}{ Brong Ahafo } & \multicolumn{2}{|c|}{ Greater Accra } \\
\hline & & $\mathrm{N}$ & Percentage (\%) & $\mathrm{N}$ & Percentage (\%) & $\mathrm{N}$ & Percentage (\%) \\
\hline \multirow{4}{*}{ Access to antibiotics } & Very easy & 140 & 57.4 & 25 & 21.9 & 6 & 14.3 \\
\hline & Easy & 98 & 40.2 & 84 & 73.7 & 36 & 85.7 \\
\hline & Difficult & 5 & 2.0 & 5 & 4.4 & 0 & 0.0 \\
\hline & Very difficult & 1 & 0.4 & 0 & 0.0 & 0 & 0.0 \\
\hline \multirow{4}{*}{ Access to information } & Very easy & 166 & 68.0 & 15 & 13.2 & 2 & 4.8 \\
\hline & Easy & 75 & 30.7 & 86 & 75.4 & 40 & 95.2 \\
\hline & Difficult & 3 & 1.2 & 12 & 10.5 & 0 & 0.0 \\
\hline & Very difficult & 0 & 0.0 & 1 & 0.9 & 0 & 0.0 \\
\hline \multirow{3}{*}{ Source of antibiotics } & Veterinary office & 194 & 79.5 & 69 & 60.5 & 30 & 71.4 \\
\hline & Vet-chem/pharma shops & 85 & 34.8 & 55 & 48.2 & 0 & 0.0 \\
\hline & Mobile sales men & 33 & 13.5 & 27 & 23.7 & 22 & 52.4 \\
\hline \multirow{4}{*}{ Source of information } & Veterinary office & 195 & 79.9 & 68 & 59.6 & 34 & 81.0 \\
\hline & Vet-chemical shop & 62 & 25.4 & 54 & 47.4 & 0 & 0.0 \\
\hline & Mobile sales men & 28 & 11.5 & 48 & 42.1 & 18 & 42.9 \\
\hline & Drug leaflets & 4 & 1.6 & 5 & 4.4 & 5 & 11.9 \\
\hline \multicolumn{8}{|c|}{$\mathrm{N}$ : number of selected farms } \\
\hline
\end{tabular}

Table 5: Accessibility to antibiotics and antibiotic related information.

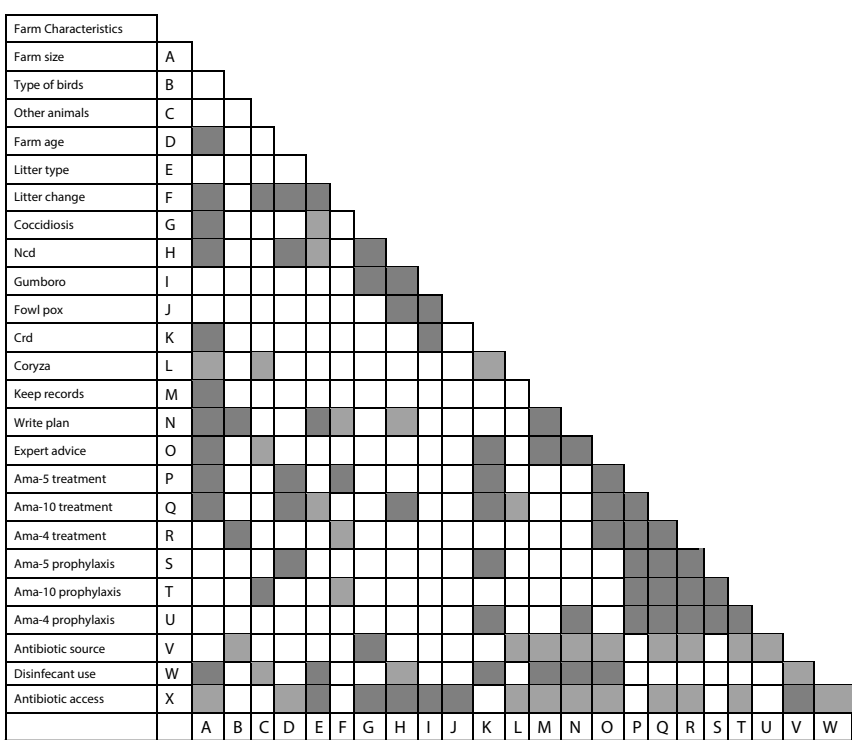

Figure 5: Spearman's correlation/relationship between farm characteristics. $\mathbb{Z}$ = Significant positive relationship. $\mathrm{Z}=$ Significant negative relationship; $\square=$ no significant relationship. and fluoroquinolone, residues in poultry eggs, milk and meat products both in Ghana [27] and other parts of the world [51-53]. The refusal of farmers to follow recommended withdrawal period, would not only lead to the continual detection of these residues in poultry products, but also contribute to the increasing resistant strains of pathogenic bacterial agents aside causing irritation and hypersensitivity reactions in humans $[7,40,54]$.

Poultry farmers in the three regions generally did not have difficulty obtaining information on antibiotics or access to antibiotics. Such information and services could easily be obtained from the veterinary office, vet-chemical shops, mobile salesmen and pharmacies (Table 5). The disadvantage of the ease of access to antibiotics is the fact that unauthorized persons could easily obtain and misuse antibiotics, which could contribute to the surge in antibiotic resistance.

The correlations between poultry farm variables revealed that in all the three regions, large farms had been in existence longer than smaller farms. It was also observed that both large farms and older farms changed their bedding material more frequently, were more likely to record treatment plans, keep treatment record, use disinfectants and seek veterinarian or expert advice than both smaller and younger farms. This could be due to the fact that larger farms could readily afford for instance, to pay for services of veterinarians since smaller farms perceive veterinary services as expensive [47]. 
It was also observed that farmers who sought veterinary advice were more likely to use higher frequencies of antibiotic-containing agents for treatment and prevention of infections. This could be due to the fact that, veterinarians in Ghana are not as much a part of farm management systems as their colleagues in developed countries [42]. As such, veterinarians in Ghana diagnose and treat infections mostly based on the information provided by farmers which could result in over and under-prescribing and possible misuse of antibiotics by farmers [49]. An improvement of delivery of veterinary services to farmers, including strict monitoring of use of antibiotics could help improve the situation.

The use of antibiotics on poultry farms was also found to be more dependent on the presence of other farm animals on the poultry farm. This could be as a result of the exposure of the birds to different kinds of infections, necessitating the need for higher amounts of antibiotics, or frequent administration of antibiotics [55]. There is also the tendency for farmers rearing more than one type of animal on the same premises to use antibiotics for prophylaxis of all animals [56] especially, when farmers are of the view that infections in one species could be transmitted from one animal to another [49].

The dependence of antibiotic-containing antimicrobial agents on bacterial infections (Table 6), as observed in this study, could be due to lapses in hygienic conditions on the farms $[7,35]$ resulting in frequent occurrences of such infections. The dependence of farmers on antibiotics for the treatment of parasitic infections could be because most farmers rely on personal knowledge and experience during antibiotic administration instead of seeking veterinarian advice [47]. It could also be due to failure of farmers to administer vaccines at the appropriate time [57].

Most of the factors observed to influence farmers' choice of antibiotics (Table 6) are factors within farmers' control. For instance occurrence of infections could be reduced by timely vaccination and improvement in farm hygienic conditions [57]. It was also observed that veterinarians are influential in the use of antibiotics on farms and improvement in delivery of veterinary services as previously suggested [47] could significantly decrease the use and possible misuse of antibiotics on these farms. Also, monitoring farmers' access to antibiotics by instituting surveillance systems may lead to a decline in the use of antibiotic-containing agents on poultry farms.

There is the need for policies and stricter regulations that would limit illegal access to antibiotics. Policy makers must also introduce programmes that would monitor the importation, sale, distribution, use and consumption of antibiotics in animal production in Ghana.

\section{Conclusion}

Poultry farmers in the three regions employed several essential antibiotics on their farms for treatment of infections and prophylaxis purposes. Both internal and external factors influenced farmers' choice and use of antibiotics on their farms and if these identified factors are not checked and monitored, can easily lead to increased antibiotic resistance among antibiotics used for the treatment of microbial infections in humans and animals. This calls for stricter regulation and monitoring of the use antibiotics in both humans and animal production.

\section{Conflict of Interests}

We, the authors, declare on conflict of interests.

\section{Acknowledgements}

The authors are grateful to the funds and grants provided by Building Stronger Universities(BSU)/DANIDA, Denmark towards the project. We appreciate the fellowships offered to VEB by L'Oreal-UNESCO Women in Science and Vice Chancellor's Office, Kwame Nkrumah University of Science and Technology, Kumasi, Ghana. We are also grateful to the officials of the Ministry of Food and Agriculture, Ashanti region, Ghana and also to the owners, managers and workers of the various poultry farms in the three selected regions in Ghana for their cooperation and support during the study.

\section{References}

1. FAO (2014) Poultry Sector Ghana. FAO Animal Production and Health Livestock Country Reviews, Rome.

2. Pinto A De, Demirag U, Haruna A, Koo J, Asamoah M (2012) Climate change, Agriculture and foodcrop production in Ghana. Int Food Policy Research Institute.

3. Speksnijder DC, Jaarsma DC, van der Gugten C, Verheij TJM, Wagenaar J (2014) Determinants associated with veterinary antimicrobial prescribing: A qualitative study. Zoonoses Public Health 62: 39-51.

4. Sumberg J, Awo M, Fiankor DD, Kwadzo GT-M, Thompson J (2013) Ghana's Poultry Sector: Limited Data, Conflicting Narratives, Competing Visions. Ghana Poultry.

5. Sonaiya EB (2007) Family poultry, food security and the impact of HPAI. World's Poult Sci J 63: 132-138.

6. Aning KG (2006) The Structure and importance of the commercial and village based poultry in Ghana. Poultry Review - Ghana.

7. Annan-Prah A, Agbemafle E, Asare PT, Akorli SY (2012) Antibiotic use, abuse and their public health implication: The contributory role of management flaws in the poultry industry in two Agro-ecological zones in Ghana. J Vet Adv 2 199-208.

8. McEwen S, Fedorka-Cray PJ (2002) Antimicrobial use and resistance in animals. Clin Infect Dis 34: S93-S106.

9. WHO (2010) WHO model list of essential medicines. WHO pp: 1-43

10. WHO (2014) Antimicrobial resistance global report on surveillance. World Heal Organ 256.

11. Tomson G, Vlad I (2014) The need to look at antibiotic resistance from a health systems perspective. Ups J Med Sci 119: 117-124.

12. Carlet J, Jarlier V, Harbarth S, Voss A, Goossens H, et al. (2012) Ready for a world without antibiotics? The Pensières Antibiotic Resistance Call to Action. Antimicrob Resist Infect Control 1: 11

13. Saana SBBM, Adu F, Agyare C, Gbedema SY, Boamah VE, et al. (2013) Antibiotic resistance patterns of strains of Staphylococcus aureus isolated from patients in three hospitals in Kumasi, Ghana. J Bacteriol Res 5: 35-40.

14. George DF, Gbedema SY, Agyare C, Adu F, Boamah VE, et al.( 2012) Antibiotic resistance patterns of Escherichia coli Isolates from hospitals in Kumasi, Ghana. ISRN Microbiol 2012: 1-5.

15. Feglo PK, Gbedema SY, Nii S, Quay A, Adu-sarkodie Y (2010) Occurrence, species distribution and antibiotic resistance of Proteus isolates: A case study at the Komfo Anokye Teaching Hospital ( KATH ) in Ghana. IJPSR 9: 347-352.

16. Donkor E, Nartey E (2007) Nasal colonisation of drug resistant bacteria in Ghanaian children less than five years. J Microbiol 5: 6 .

17. Ohene A (1997) Bacterial pathogens and their antimicrobial susceptibility in Kumasi, Ghana. East Afr Med J 74: 450-455.

18. Dayie NTKD, Arhin RE, Newman MJ, Dalsgaard A, Bisgaard M, et al. (2013) Penicillin resistance and serotype distribution of Streptococcus pneumoniae in Ghanaian children less than six years of age. BMC Infect Dis 13: 7.

19. Turkson PK (2008) Use of drugs and antibiotics in poultry production in Ghana Ghana J Agric Sci 41. 
Citation: Boamah VE, Agyare C, Odoi H, Dalsgaard A (2016) Practices and Factors Influencing the Use of Antibiotics in Selected Poultry Farms in Ghana. J Antimicro 2: 120. doi:10.4172/2472-1212.1000120

20. European Union (1998) Report of the scientific committee for animal nutrition on the efficacy and risk for users of the therapeutic macrolides antibiotics Tylosin and Spiramycin used as feed additives. p: 8.

21. Mainda G, Bessell PB, Muma JB, McAteer SP, Chase-Topping ME, et al. (2015) Prevalence and patterns of antimicrobial resistance among Escherichia coli isolated from Zambian dairy cattle across different production systems. Sci Rep 5: 12439.

22. Teillant A (2015) Costs and benefits of antimicrobial use in Livestock. Anim Husbandry Antimicrob Resist 8: 116-122.

23. Chilonda P, Van Huylenbroeck G (2001) A conceptual framework for the economic analysis of factors influencing decision-making of small-scale farmers in animal health management. Rev Sci Tech 20: 687-700.

24. Van den Bogaard E, Stobberingh EE (2000) Epidemiology of resistance to antibiotics. Links between animals and humans. Int $\mathrm{J}$ Antimicrob Agents 14: 327-335

25. Persoons D, Dewulf J, Smet A, Herman L, Heyndrickx M (2010) Prevalence and persistence of antimicrobial resistance. Microb Drug Resist 16: 67-74.

26. Wimalarathna HML, Richardson JF, Lawson AJ, Elson R, Meldrum R et al. (2013) Widespread acquisition of antimicrobial resistance among Campylobacter isolates from UK retail poultry and evidence for clonal expansion of resistant lineages. BMC Microbiol 13: 160

27. Donkor ES, Newman MJ, Yeboah-Manu D (2012) Epidemiological aspects of non-human antibiotic usage and resistance: Implications for the control of antibiotic resistance in Ghana. Trop Med Int Heal 17: 462-468.

28. Sekyere JO, Adu F (2015) Prevalence of multidrug resistance among Salmonella enterica Serovar Typhimurium Isolated from Pig faeces in Ashanti Region, Ghana. Int J Antibio 4.

29. Ghana Statistical Service (2012) 2010 Population and Housing Census. Sakoa Press L imited, Accra.

30. MOFA (2011) Agriculture in Ghana: Facts and figures. Accra, Ghana Stat Res Inf Dir.

31. Ministry of Health (GNDP) Ghana (2010) Standard Treatment Guidelines (6th edn), Yamens Press Ltd, Ghana.

32. Lowy FD (2003) Antimicrobial resistance: the example of Staphylococcus aureus. J Clin Invest 111: 1265-1273.

33. Gyansa-Lutterodt M (2013) Antibiotic resistance in Ghana. Lancet Infect Dis 13: $1006-1007$

34. Bal A (2012) Ghana is balancing on the table egg market. World Poultry News, Knowledge and Career.

35. Msoffe PL, Aning KG, Byarugaba DK, Mbuthia PG, Sourou S, et al. (2009) Handbook of poultry diseases important in Africa. A Project of the Global Livestock CRSP pp: 83

36. Amaral $L$ (2004) Drinking water as a risk factor to poultry health. Brazilian $J$ Poult Sci 6: 191-199.

37. Mubito EP, Shahada F, Kimanya ME, Buza JJ (2014) Antimicrobial use in the poultry industry in Dar-es-Salaam, Tanzania and public health implications. Am J Res Commun 2: 51-63.

38. Giguère S, Prescott JF, Dowling PM (2013) Antimicrobial therapy in veterinary medicine. (5th edn), Wiley Blackwell pp: 675

39. Glisson JR (1998) Bacterial respiratory disease of poultry. Poult Sci 77: 11391142.

40. Darwish WS, Eldaly E, El-Abbasy MT, Ikenaka Y, Nakayama S, et al. (2013) Antibiotic residues in food: The African scenario. Jpn J Vet Res 61: S13-S22.

41. Gilbert N (2012) Rules tighten on use of antibiotics on farms. Nature 481: 125

42. Cogliani C, Goossens H, Greko C (2011) Restricting Antimicrobial use in food animals: Lessons from Europe. Microbe 6: 274-279.

Citation: Boamah VE, Agyare C, Odoi H, Dalsgaard A (2016) Practices and Factors Influencing the Use of Antibiotics in Selected Poultry Farms in Ghana. J Antimicro 2: 120. doi:10.4172/2472-1212.1000120
43. Kohanski M, Dwyer DJ, Collins JJ (2010) How antibiotics kill bacteria: from targets to networks. Nat Rev Microbiol 8: 423-435.

44. Amaechi N (2014) A Survey on antibiotic usage in pigs and poultry birds in Abia State, Nigeria. Glob J Med Res C Microbiol Pathol 14: 9.

45. Oluwasile BB, Agbaje M, Ojo OE, Dipeolu MA (2014) Antibiotic usage pattern in selected poultry farms in Ogun state. Sokoto J Vet Sci 12: 45-50.

46. Maron DF, Smith TJS, Nachman KE (2013) Restrictions on antimicrobial use in food animal production: an international regulatory and economic survey. Global Health 9: 48.

47. Turkson PK (2009) Clients' perceptions of delivery of veterinary services in periurban Ghana. Trop Anim Health Prod 41: 121-128.

48. Davies J, Davies D (2010) Origins and evolution of antibiotic resistance. Microbiol Mol Biol Rev 74: 417-433.

49. Garforth C (2015) Livestock keepers' Reasons for doing and not doing things which governments, vets and scientists would like them to do. Zoo Public Health 62: 29-38.

50. Mirlohi M, Aalipour F, Jalali M (2013) Prevalence of antibiotic residues in commercial milk and its variation by season and thermal processing methods. Int J Envi Health Eng 2: 41

51. Er B, Onurdag FK, Demirhan B, Ozgacar SÖ, Oktem AB, et al. (2013) Screening of quinolone antibiotic residues in chicken meat and beef sold in the markets of Ankara, Turkey. Poult Sci 92: 2212-2215.

52. Adewuyi GO, Olatoye OI, Abafe AO, Otokpa MO, Nkukut NK (2011) High performance liquid chromatographic method for evalustion of two antibiotic residues in liver and muscle of broilers in Ibadan city, Southern Nigeria. $J$ Pharm Biomed Sci 11: 1-4.

53. Mbodi FE Nguku P Okolocha E Kabir J (2014) Determination of chloramphenicol residues in commercial chicken eggs in the Federal Capita Territory, Abuja, Nigeria. Food Addit Contam Part A Chem Anal Control Expo Risk Assess 31: 1834-1839.

54. Hakem A, Titouche Y, Houali K, Yabrir B, Malki O, et al. (2013) Screening of antibiotics residues in poultry meat by microbiological methods. Bull UASVM, Vet Med 70: 77-82

55. Sekyere JO (2014) Antibiotic types and handling practices in disease management among pig farms in Ashanti Region, Ghana. J Vet Med 8.

56. Callens B, Persoons D, Maes D, Laanen M, Postma M, et al. (2012) Prophylactic and metaphylactic antimicrobial use in Belgian fattening pig herds. Prev Vet Med Elsevier 106: 53-62

57. Blackall PJ (1999) Infectious coryza: Overview of the disease and new diagnostic options. Clin Microbiol Rev 12: 627-632.

OMICS International: Publication Benefits \& Features Unique features:

- Increased global visibility of articles through worldwide distribution and indexing

- Showcasing recent research output in a timely and updated manner

Special issues on the current trends of scientific research

Special features:

- $700+$ Open Access Journals

$50,000+$ Editorial team

Rapid review process

Quality and quick editorial, review and publication processing

- Indexing at major indexing services

Sharing Option: Social Networking Enabled

Authors, Reviewers and Editors rewarded with online Scientific Credits

Better discount for your subsequen

Submit your manuscript at: www.omicsonline.org/submission/ 